\title{
Nedfarten til dødsriget
}

\author{
Af Jakob Balling
}

»Kristus nedfaret til dødsriget « - det er noget vi ser fremstillet på Joakim Skovgaards berømte maleri, såvel som på en mængde andre billeder. Det er også noget, vi ligesom alle andre i de vestlige kirker hører og måske fremsiger i kor som en ultrakort bekendelsesformel om søndagen. Og det er noget, vi læser om i Grundtvigs »I kvæld blev der banket på helvedes port", såvel som noget, vi synger om, når Salmebogens nr. 191 står på tavlen (»I dødens bånd vor frelser lå ... forstyrret har han dens rige ... Det var en tvekamp underfuld, da liv og død de brødes, og kredsen skreves under muld, hvor riget var de dødes; men livet fik dog overhånd, så, fængslet i sit eget bånd, til spot er nu døden blevet«) eller nr 213, med ordene »Vær velkommen fra de døde, alle djævles skræk og gru

Men det er ikke noget, vi kan få nærmere rede på i Skriften, hvor det ikke foreligger som noget, der bare ligner en begivenhedsskildring, ud over de problematiske henvisninger i Første Petersbrev 3:19f og 4:6 om Kristi prædiken for ånderne i fængsel og om evangeliets forkyndelse for de døde.

Og hvad der nærmere skal forstås ved bekendelsesformlen sådan som den kan konstateres at have været til stede fra midt i det 4 . århundrede, er et meget åbent spørgsmål, ikke blot nu om dage, da der sjældent tales mere udførligt om den og hvor mange vil være enige med den store tyske lærde, Adolf v. Harnack (1851-1930), der kaldte den en »indtørret levning «, men også i århundrederne forud, hvor den ganske vist har været genstand for intense overvejelser fordi mange var enige med Grundtvig om, at det var en salighedssag, at »Guds Søn haver helvede gæstet «, men hvor disse overvejelser er faldet særdeles forskelligt ud, akkurat som det går enhver fortælling om det, der går ud over den dagligdags erfaring og hvis mening ikke kan udtømmes ved én udlægning. Med andre ord: akkurat som det går enhver myte i dette ords prægnante og kristeligt relevante betydning: en billedlig fortælling, som på én gang siger noget om en fortidig krise-, epoke- eller oprindelsesbegivenhed $\mathrm{og}$ om vor nutid såvel som om al mellemliggende - og for den sags skyld al forestående - tid.

Men netop fordi det gennem alle århundrederne fra den tidlige oldkirke til Grundtvig og Skovgaard har været en fortælling, man ikke har kunnet eller villet ryste af sig, en som udtrykte noget umisteligt 
uanset det gådefulde ved den - netop derfor er der god mening i at betragte nogle af dens fataliteter gennem den gamle verdens århundreder og overveje spørgsmålene om hvorfor og især hvordan.

Det er, hvad jeg vil gøre nogle alt andet end udtømmende bemærkninger om i det følgende.

Nedfarten var som sagt først led af bekendelsen fra 4. århundrede. Men det skete kun fordi ideen havde vokset sig stærk fra i hvert fald 2. århundrede. Hvorfor blev den anset for så vigtig, at bekendelsen af den blev salighedssag gennem indføjelsen i dåbsbekendelsen?

Det kan der gives forskellige bud på. Et af dem er vel det motiv, der udgøres af bekymring for afdøde slægtninges skæbne. Men vigtigere er to langt mere omfattende motiver:

For det første den centrale oldkirkelige ovebevisning om sammenhængen mellem den gamle og den nye pagt, om de førkristne retfærdige, og om Kristus som inkarnationen af Guds Logos, hans skabende og ordnende fornuft. På det grundlag kan det tros, at frelsen er kommet til de døde, at altså, som det hedder hos en oldkristen forfatter: »Dødsrigets porte åbner sig. I, som er døde, glæd jer! I, som sad i mørke og dødens skygge, tag imod det store lys! Herren dvæler blandt tjenerne ... Lyset uden aften hos dem i mørket, Befrieren hos de fangne!«

Det andet store motiv leveres af den oldkirkelige forståelse af Kristi handling som kamp med og sejr over død og djævel. Det er, hvad der f.eks. fremgår af en nadverbøn fra 3. århundrede, hvor det hedder: »Han, som efter at være blevet forrådt til den frivillige lidelse for at gøre døden til intet, og bryde djævelens lænker, og trampe Hades under fode, og bringe lys til de retfærdige ... tog et brød, takkede og sagde ...«. Og ikke mindre klart fremgår det af en af Augustin citeret påskelørdagsteksts ord: »Han, der holdt det første menneske fangen, er selv blevet taget til fange. Idag brød vor Frelser dødens porte og spærrebomme; han lagde helvedes indelukke øde og omstyrtede djævelens vælde«.

Mere eller mindre udtrykkeligt findes disse to motiver sammensmeltet i den dramatisk udfoldede fortælling om, hvordan Kristus brød ind i underverdenen, sprængte dødsrigets porte, prædikede for de døde, som i deres liv havde håbet på hans komme, fór hærgende frem mod de magter, der holdt dem fangne, og førte dem med sig op i lyset.

Den historie foreligger $i$ en af sine rigest udspundne og mest indflydelsesrige former i det såkaldte Nikodemusevangelium fra 4. århundrede. 
Her møder vi to mænd, om hvem det fortælles, at de er sønner af den gamle Simeon fra Jesu barndomshistorie, og at de er iblandt de »hensovede hellige«, som ifølge Mattæusevangeliets kapitel 27 stod op af deres grave ved Kristi død og "viste sig for mange« efter hans opstandelse. De beretter om, hvad de har set: om et lys, der brød ind i mørket som sol ved midnat og faldt på alle døde fra verdens skabelse; om patriarkers og profeters glæde; om Døberen, der forkyndte, at det var Guds Søn, der kom herind for at redde enhver, der tror på ham; og om Adam, det første menneske, der viste sig og talte til sine medfangne. Videre hører vi om Satan, der kommer og taler til Hades, dødsrigets hersker, om Jesus som den, der har gjort ham megen skade, men som jo kun er menneske, »bedrøvet til døden « som han jo var. Nu har jeg ladet jøderne slå ham ihjel, fang du ham nu og spær ham inde! Hades, som jo har gjort sin erfaring med Lazarus, er betænkelig; han advarer Satan: bring ham ikke herned! Så lyder der pludselig en kæmperøst: »I herskere, åbn jeres porte, løft jer, I evige porte, Herlighedens Konge drager ind «. Hades spørger: »Hvem er denne Herlighedens Konge? «nglene svarer: »Han er Herren, stærk og vældig, Herren, vældig i strid!« Så sønderslås portene; de dødes lænker brister; Herlighedens konge drager ind; og alle dødsrigets krinkelkroge lyses op. Frelseren griber Satan om hovedet; lader englene lægge ham i lænker og giver Hades ham til forvaring. Han rækker sin højre ud; griber Adam ved hånden og rejser ham op idet han siger: "Kom til mig, alle I som måtte dø ved det træ Adam greb efter. Thi se, jeg opvækker jer alle ved korsets træ«. Endelig korstegnes alle på deres pander og deres opstigning sker under lovsangen: " Velsignet være han som kommer i Herrens navn«.

Det er såvel et omfattende kompleks af trospåstande som hele den hellige historie, vi finder samlet i omstøbt form i denne højdramatiske populære fortælling. Det vil jeg ikke dvæle udførligt ved; jeg peger kun på to karakteristiske enkeltheder. For det første: brugen af Salme 24, hvis indledende passage det er mere end nærliggende at formode, at forfatter og læsere har medtænkt: »Jorden med alt hvad den rummer, verden $0 \mathrm{~g}$ dens beboere tilhører Herren, for han har grundlagt den på havene, grundfæstet den på strømmene«. Derved inddrages al histories begyndelse og al mellemliggende historie $\mathrm{i}$ den nu fortalte frelsesbegivenhed. For det andet: den rent ud geniale fiktion, at de to frelste fortællere er sønner af den Simeon, som havde taget Jesusbarnet i sine arme og lovprist Gud for den frelse han har set, lyset til åbenbaring for hedninger, herligheden for Israels folk. På den måde gøres det klart, at 
Frelserens handling i dødsriget forudsætter hele hans optræden og virksomhed fra første begyndelse. Sådanne detaljer er betegnende for den måde, hvorpå den gamle kristenhed gjorde sin overbevisning om historisk sammenhæng, om fortidens inddragelse og liv i nutiden gældende.

Elementer fra denne dramatiske fortælling kan konstateres at være inddraget og aktualiseret på mangfoldige måder i de følgende århundreders gudstjenesteliv - og teaterhistorie; grænsen var flydende i europæisk middelalder! Jeg vælger to eksempler på denne liturgisk-dramatiske brug, et fra hver sin ende af middelalderen. Begge røber noget karakteristisk for gammel europæisk kristendom og siger noget oplysende om, hvordan nedfartsfortællingen kan tjene som levendegørende og nutidiggørende sammenfatning af frelsesbegivenheder og trospåstande.

Det ene findes i et kirkeindvielsesritual fra 9. århundrede. Det foreskriver, at en præst med følge skal indfinde sig ved kirkeporten og kræve den åbnet. En anden præst råber derindefra: »Hvem er den Herlighedens Konge? « og får svaret: »Det er Herren, stærk og vældig, Herren, vældig i strid «. Efter gentagelse åbnes porten, processionen drager ind, og manden indefra forsvinder.

Her findes ideen og historien om kamp og sejr i dødsriget bragt $i$ anvendelse på noget, som man har villet tolke i dette temas lys, eller rettere: man har villet lade urbegivenheden få nutidig realitet ved det, man nu foretager sig i den nutidige krisesituation: hellighedens angreb på den uindviede og altså djævlebeherskede kirkebygning. Det sker, ligesom i Nikodemusevangeliet, i dramatisk form, således som det ikke mindst fremgår af, at præsten inde i kirken »spiller« djævelen, en rolle han formodentlig har forlenet med al ønskelig applomb. Men vigtigst er, som antydet, den omstændighed, at renselsen af kirkebygningen manifesteres som Kristi eget værk ved at hans handling i dødsriget bliver tolkningsredskab derfor.

Det andet eksempel har mere direkte med påskebegivenhederne at gøre. Det er et »korsrejsningsritual« fra 15. århundrede. Korset, som har været »gravlagt « siden Langfredag, bliver taget op af biskoppen i påskenatten; man bevæger sig derefter i procession rundt om kirken med det tilhyllede nadverbrød, manifestationen af Kristi selvhengivelse på korset; det sker under sang med hentydninger til nedfart, portnedbrydelse og befrielse. Ved kirkeporten rejses kravet fra salme 24: »Løft jer, I ældgamle døre « og der bankes tre gange på den med bispestaven. En „djævelsk" forvrænget diakonstemme lyder indefra med salmens 
spørgsmål, og dens svar gives. Så åbnes porten, og processionen af gejstlighed og lægfolk bevæger sig op til højaltret, hvor det nu utilhyllede nadverbrød vises og tilbedes. Triumfsangen $» O$, højværdige offer « synges, med ordene om hvordan ved dette offer »dødsriget er blevet sønderbrudt og det fangne folk genløst «.

Atter her ser vi, hvordan den fortidige frelseshandling inddrages $i$ nuets tid og rum, ganske som det forudsattes i de ovenfor citerede tidlige tekster: nadverbøn og påskelørdagsritual. Derudover er det værd at bemærke, hvordan den fremtidige herlighed antydes - og i den forstand findes inddraget i nuet - gennem lægfolkets tilstedeværelse ved alteret.

Hvad der hidtil har været på tale har haft »kollektiv« karakter. Jeg vender mig til en betragtning af nedfartsideens anvendelse på enkeltpersonens plan.

I Dantes "guddommelige« Komedie udgøres den røde tråd af den vandrende jegpersons læreproces og identitetserhvervelse $\mathrm{i}$ helvede, på renselsesbjerget og $\mathrm{i}$ himmelsfærerne. Under vandringen indoptager han historie og verdensorden i sig og forvandles derved. Et af elementerne i denne proces er den gradvise erfaring i helvede af, at Kristus har været der før. Vandreren ser ruiner og forstår dem ikke, siden går det op for ham, hvorfor de er ruiner. Og han forstår, at hvorfor og hans egen nedstigning er begyndt på Langfredag og at opstigningen til lyset finder sted på Påskedag. Der er altså tale om en personlig tilegnelse af Kristi nedfart og genopstigning. Dertil føjer sig så endnu en pointe: Der er endnu én, der har været der før, nemlig Beatrice, vandrerens døde ungdomselskede, der, som det hedder, har sat sin fod i helvede for hans skyld, som det sendebud ovenfra, der skal sætte ham ind på den store erfarings vej, altså begynde hjemhentningen af den vildfarne. Det er uundgåeligt at mindes Grundtvig ved læsningen af passagerne om Beatrice. I dén sidste nattevagt, som jegpersonens rejse udgør, er Kristus kommet til ham i hans kæres dragt.

En noget anderledes nedfartsrefleksion med sigte på enkeltpersonen er den, man kan møde hos mystikerne. Og også hos Luther. Hans tolkning af nedfarten som Kristi »overtagelse af menneskelig anfægtelse og fortvivlelse; han har overvundet Helvede idet han udsatte sig for det«, som det hedder i artiklen »Höllenfahrt Christi« i Theologische Realenzyklopädie. Her er nedfartsideen i en vis forstand blevet afmytologiseret (således som den jæunthen er blevet det i de følgende århundreder så længe man overhovedet interesserede sig for den): dens mening forstås som det kristne enkeltmenneskes erfaring af den dom og befrielse 
i ét som er Kristusbegivenhedens tale til ham, dens tale om hans delagtighed i historien om skabelse, fald og genoprejsning. Men det er rigtignok værd at supplere dén konstatering med det, jeg citerede i begyndelsen, altså Grundtvigs gendigtning af Luthers salme »Christ lag in Todesbanden«. Luther slipper ikke myten; hans »afmytologiserende«, »subjektive « udsagn er en tolkning af den myte, han holder fast på, fordi den formidler den udefra kommende, »objektive« begivenheds tiltale, om hvilken der til syvende og sidst ikke kan tales på anden måde. »Es war ein wunderlich Krieg", synger han, "Da Tod und Leben rungen. Das Leben behielt den Sieg. Es hat den Tod verschlungen. Die Schrift hat bekundet das, wie ein Tod den andern fraß. Ein Spott aus dem Tod ist worden «. Hvad Grundtvig angår, markerer han - måske typisk nok den gamle tradition tydeligere end Luther: $\gg$ Det var en tvekamp underfuld, da liv og død de brødes, og kredsen skreves under muld, hvor riget var de dødes; men livet fik dog overhånd, så, fængslet i sit eget bånd, til spot er nu døden blevet «. Ikke for ingenting lyder der i disse linjer en genklang af en ældgammel tradition, den som Wipo i sin påskesekvens fra 11. årh. netop formulerede med ordene: »Mors et vita duello / conflixere mirando«: »død og liv udkæmpede en underfuld tvekamp«.

Nedfartsfortællingen eller -myten har gjort tjeneste i kristenheden så mange århundreder igennem, at man efter min mening skylder den at lytte til den i dens egenskab af at være sammenfattende bærer og konkretiserende formidler af et mere end almindeligt omfattende kompleks af centrale kristne trosudsagn. Jeg er en varm beundrer af mit fags førstemand, Adolf von Harnack; men når han kalder »nedfaren til dødsriget « for en »vertrocknete Reliquie«, en »indtørret levning«, skilles vore veje for en stund.

Bibliografisk note: Nedfartsideens optræden i kristen såvel som ikkekristen sammenhæng er indgående skildret i Josef Kroll: Gott und Hölle: Der Mythos vom Descensuskampfe, 1932, genoptrykt 1963. Desuden den ovenfor nævnte artikel i Theologische Realenzyklopädie samt min Poeterne som Kirkeloerere. 